\title{
Human Rights and the OECD Guidelines for Multinational Enterprises: Normative Innovations and Implementation Challenges Faculty Research Working Paper Series
}

\section{John Ruggie}

Harvard Kennedy School, Corporate Social Responsibility Initiative

\section{Tamaryn Nelson}

Harvard Kennedy School, Corporate Social Responsibility Initiative

\section{August 2015 RWP15-045}

Visit the HKS Faculty Research Working Paper Series at:

https://research.hks.harvard.edu/publications/workingpapers/Index.aspx

The views expressed in the HKS Faculty Research Working Paper Series are those of the author(s) and do not necessarily reflect those of the John F. Kennedy School of Government or of Harvard University. Faculty Research Working Papers have not undergone formal review and approval. Such papers are included in this series to elicit feedback and to encourage debate on important public policy challenges. Copyright belongs to the author(s). Papers may be downloaded for personal use only. 


\section{Human Rights and the OECD Guidelines for Multinational Enterprises: Normative Innovations and Implementation Challenges}
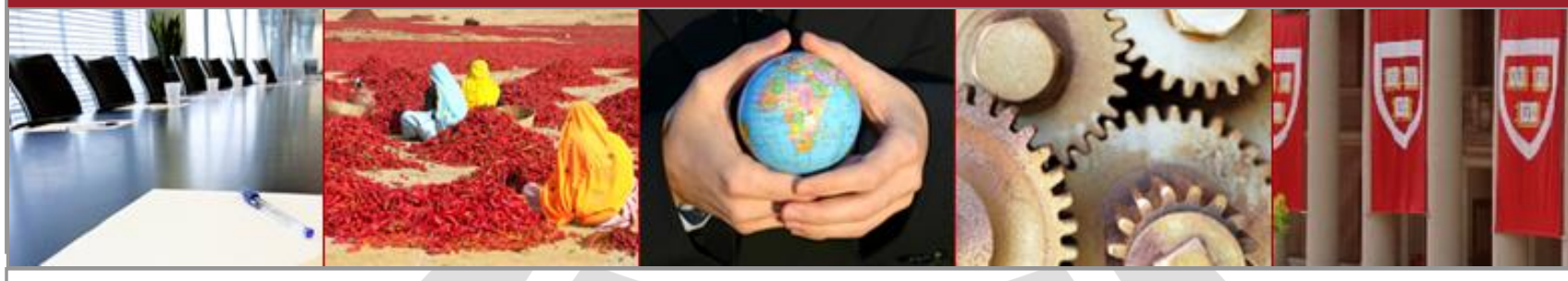

\section{John Ruggie}

Corporate Social Responsibility Initiative, Harvard Kennedy School

\section{Tamaryn Nelson}

Corporate Social Responsibility Initiative, Harvard Kennedy School

May 2015 | Working Paper No. 66

A Working Paper of the:

Corporate Social Responsibility Initiative

A Cooperative Project among:

The Mossavar-Rahmani Center for Business and Government

The Center for Public Leadership

The Hauser Center for Nonprofit Organizations

The Joan Shorenstein Center on the Press, Politics and Public Policy 


\section{Citation}

This paper may be cited as: Ruggie, John G., and Tamaryn Nelson. 2015. "Human Rights and the OECD Guidelines for Multinational Enterprises: Normative Innovations and Implementation Challenges." Corporate Social Responsibility Initiative Working Paper No. 66. Cambridge, MA: John F. Kennedy School of Government, Harvard University. Comments may be directed to the authors

\section{Corporate Social Responsibility Initiative}

The Corporate Social Responsibility Initiative at the Harvard Kennedy School of Government is a multi-disciplinary and multi-stakeholder program that seeks to study and enhance the public contributions of private enterprise. It explores the intersection of corporate responsibility, corporate governance and strategy, public policy, and the media. It bridges theory and practice, builds leadership skills, and supports constructive dialogue and collaboration among different sectors. It was founded in 2004 with the support of Walter H. Shorenstein, Chevron Corporation, The Coca-Cola Company, and General Motors.

The views expressed in this paper are those of the authors and do not imply endorsement by the Corporate Social Responsibility Initiative, the John F. Kennedy School of Government, or Harvard University.

\section{For Further Information}

Further information on the Corporate Social Responsibility Initiative can be obtained from the Program Coordinator, Corporate Social Responsibility Initiative, Harvard Kennedy School, 79 JFK Street, Mailbox 82, Cambridge, MA 02138, telephone (617) 495-1446, telefax (617) 496-5821, email CSRI@hks.harvard.edu.

The homepage for the Corporate Social Responsibility Initiative can be found at: www.hks.harvard.edu/centers/mrcbg/programs/csri 


\title{
HUMAN RIGHTS AND THE OECD GUIDELINES \\ FOR MULTINATIONAL ENTERPRISES: \\ NORMATIVE INNOVATIONS AND \\ IMPLEMENTATION CHALLENGES*
}

\author{
John Gerard Ruggie and Tamaryn Nelson
}

John Gerard Ruggie is the Bertholz Beitz Professor in International Affairs and Human Rights at Harvard's Kennedy School of Government, and Affiliated Professor in International Legal Studies at Harvard Law School. He has also served as United Nations Assistant SecretaryGeneral for Strategic Planning, and as the UN Secretary-General's Special Representative for Business \& Human Rights. His most recent book, Just Business: Multinational Corporations and Human Rights, has been translated into Chinese, Japanese, Korean, Spanish and Portuguese. He is a Fellow of the American Academy of Arts \& Sciences, and in 2014 he received the Washington Foreign Law Association's annual award to the individual who made the most important contribution to the development and implementation of international law.

Tamaryn Nelson received her Masters in Public Administration from the Kennedy School in 2014, where she was a Jorge Paulo Lemann Fellow, focusing on business and human rights. Currently she is a researcher at the Kennedy School's Corporate Social Responsibility Initiative. Previously, she led Amnesty International's research in Ecuador, Peru and Venezuela and Planned Parenthood's Global Advocacy Program. From 2003-2010, Nelson led the Latin America Program at WITNESS, an NGO founded by musician Peter Gabriel that uses video to document human rights abuses. She began her career at the Pan American Health Organization and at the Center for Justice and International Law. Originally from Brazil, her undergraduate degree is from Georgetown University's School of Foreign Service and she has a Certificate in International Human Rights Law from Oxford University.

*The authors are deeply indebted to participants in the OECD National Contact Point system and other experts closely involved in it for their helpful input and suggestions for improving earlier drafts, all of whom were promised anonymity. 


\section{INTRODUCTION}

Business and human rights became an increasingly prominent feature on the international agenda in the 1990s. Global markets widened and deepened significantly as a result of trade liberalization, privatization, deregulation, and off-shoring production as well as financial centers. The rights of multinational corporations to operate globally became legally enshrined in a vast expansion of bilateral investment treaties and investment chapters of bilateral and regional free trade agreements, as well as a new international regime protecting intellectual property. According to one UN study, some 94 percent of all national regulations related to foreign investment that were modified in the decade from 1991 to 2001 were intended to facilitate it. ${ }^{1}$ Multinational corporations did well subsequently, and so too did people and countries that were able to take advantage of the opportunities created by this transformative process.

But others were less fortunate. Global social and environmental protections lagged behind, and domestic safety nets, where they existed at all, began to fray. Income inequalities began to rise. International attempts to regulate the conduct of multinational corporations, going back to the 1970s, continued to fail. Sweatshops, displaced communities, child labor, forced and bonded labor, corporate security providers raping and sometimes killing demonstrators or mere bystanders, are among the abuses that were amply documented. What requires better documentation, if these global imbalances are to be corrected, are the means by which the global and local communities have sought to redress the imbalances, and how they might be improved.

This paper takes one small step in that direction. It analyzes the first and still one of the very few international mechanisms that governments have established enabling individuals, communities or their representatives to bring complaints against multinational corporations: the Guidelines for Multinational Enterprises ("Guidelines") promulgated by the Organization for Economic Cooperation and Development (OECD). Our interest in the Guidelines in this paper is two-fold. First, we want to identify patterns of use over time in order to better understand them. Second, we want to see what if any difference exists in these patterns since the endorsement by the United Nations Human Rights Council in 2011 of the Guiding Principles on Human Rights, core elements of which were incorporated into the 2011 OECD Guidelines revision. Finally, we offer some concluding thoughts about how this complaints mechanism should be strengthened.

\section{A BRIEF HISTORY}

\section{THE ORIGINAL GUIDELINES}

In1976, on the eve of United Nations negotiations on a Code of Conduct on Transnational Corporations, which was abandoned some fifteen years later, the OECD adopted a Ministerial Declaration on International Investment and Multinational Enterprises. It was the first 
multilateral instrument to include the principle of "national treatment" in the investment context: according foreign-controlled enterprises treatment "consistent with international law and no less favorable than that accorded in like situations to domestic enterprises."2 Perhaps in an attempt to couple this principle with a recognition of responsibilities on the part of multinational corporations, the Declaration annexed a set of "recommendations" that the OECD member states addressed to multinational enterprises - the original OECD Guidelines for Multinational Enterprises. OECD member states were obligated to promote the Guidelines, while the recommendations to multinationals were non-binding. Multinationals were advised to comply with national laws, encouraged to make a positive contribution to economic and social progress in their countries of operation, contribute to technology transfer, and not harm the environment. Apart from freedom of association and the right to bargain collectively, which are recognized in International Labor Organization conventions, the Guidelines referenced no other international standards in relation to human rights. ${ }^{3}$ In 1984, OECD members agreed to establish so-called National Contact Points (NCPs), an office within each government whose job it would be not only to promote the Guidelines, but also "to contribute to the solution of problems which may arise" related to the observance of the Guidelines ${ }^{4}$ - in short, a complaints mechanism, which the OECD refers to as "specific instances." Organized labor subsequently sought such help on a number of occasions in connection with anti-union activities by companies, but by the 1990s this mechanism had "slumped into disuse." Companies were not obliged to participate in the complaints process, and if a National Compact Point (NCP) agreed with a complaint the sole consequence was that it could issue a report to this effect.

Following the collapse of the OECD negotiations on a Multilateral Agreement on Investment (MIA) in 1998, whose critics (including several member states) charged that it excessively favored the rights of investors over public interest considerations, the OECD revised the Guidelines in 2000. ${ }^{7}$ Corporate observance was still voluntary. But the Guidelines' scope was expanded as OECD-based multinationals were "encouraged" to follow them wherever they operated, not only in OECD countries. In addition, firms were advised to respect the human rights of those affected by their activities "consistent with the host government's obligations and commitments" - that is, consistent with whatever international human rights treaties a host government may, or may not, have ratified. Disclosure of information regarding company activities, finances and performance was encouraged; the elimination of forced and child labor were added to the labor provisions; and basic principles of environmental management were laid out. The revised Guidelines also stipulated that companies should not offer or demand bribes, and that they should meet minimum consumer protection standards, facilitate technology transfer "where practicable," refrain from engaging in anti-competitive practices, and pay their taxes. The OECD also began to encourage non-member states to adhere to the Guidelines.

The 2000 revision sought to breathe new life into the moribund NCPs system. Between 2000 and mid-2009 an estimated 189 complaints ("specific instances") were filed with NCPs (summarized in Figure 1, below). ${ }^{8}$ All cases were brought by labor unions and NGOs. The number of new cases referred rose to 17 in 2001-2002, and then to 35 the following year partly for specific reasons addressed below. By 2008 complaints filed declined back to 16 . Under the 2000 Guidelines NCPs considered roughly 40 percent of the cases submitted to be inadmissible. 
Because the Guidelines were linked to the Declaration, one of the most common basis for excluding cases was the lack of an "investment nexus" - often because the multinational involved did not hold equity in the enterprise in question. It often was a buyer or a supplier, or a financial institution that enabled an investment without being a direct investor. ${ }^{9}$ And there the matter stood until 2011.

\section{THE UN PROTECT, RESPECT AND REMEDY FRAMEWORK}

In the late 1990s, the UN Sub-Commission on Human Rights, comprising experts acting in their personal capacity, began to draft a treaty-like document called the "Norms on the Responsibilities of Transnational Corporations and Other Business Enterprises with regard to Human Rights." Among other features, the draft Norms sought to impose on companies, directly under international law, essentially the same range of human rights duties that States have accepted for themselves under treaties they have ratified: "to promote, secure the fulfillment of, respect, ensure respect of and protect human rights." 10 This would have so intermingled the respective roles of States and business that it would have been impossible to determine who was responsible for what on the ground. In 2004, the intergovernmental parent body, the Commission on Human Rights (now Human Rights Council) rejected the proposal, stating (impolitely by UN standards) that it had not asked for it and that the text had no legal status. Instead, at its next meeting a year later the Commission requested UN Secretary-General Kofi Annan to appoint a Special Representative (SRSG) to start the process afresh. Annan appointed Professor John Ruggie, this paper's co-author, to that position.

Ruggie has told the story of the mandate elsewhere. ${ }^{11}$ Initially, he was asked to merely "identify and clarify" existing standards and best practices, as well as such contested concepts as "corporate complicity" and "spheres of influence," which he did in voluminous reports. He was also invited to offer recommendations. In 2008, at the end of his three-year mandate, he made only one: that the Human Rights Council agree that the most effective way to conceptualize the way forward was through what he called the "Protect, Respect and Remedy" Framework, which he elaborated in his final report. ${ }^{12}$ The Framework rests on three pillars:

1. The state duty to protect against human rights abuses by third parties, including business, through appropriate policies, regulation, and adjudication;

2. An independent corporate responsibility to respect human rights, which means that business enterprises should act with due diligence to avoid infringing on the rights of others and to address adverse impacts with which they are involved;

3. Greater access by victims to effective remedy, judicial and non-judicial.

The Council "welcomed" the Framework and extended Ruggie's mandate for another three years, asking him to "operationalize" it. Various stakeholder groups, including governments, businesses, workers organizations, NGOs and others, began referencing the Framework almost immediately. NGOs as well as workers organizations drew on the Framework in lodging new complaints to OECD NCPs, which in part accounts for the increase in cases in 
the cycles 2010-2011 that we see in Figure 1. Two NCP cases are particularly noteworthy because they signaled future developments.

\section{DAS Air}

A United Nations Panel of Experts on the Illegal Exploitation of Natural Resources and Other Forms of Wealth of the Democratic Republic of Congo (DRC) delivered its final report to the UN Security Council in October 2003. ${ }^{13}$ It identified approximately 125 companies and individuals for allegedly having contributed directly or indirectly to the conflict in the DRC, in which ultimately perhaps as many as five million people were killed. The companies included multinational enterprises operating within or from countries adhering to the OECD Guidelines. Thus the panel specifically requested that those governments address those cases.

Based on the report, in 2004 the British NGO, Rights and Accountability in Development (RAID), brought a case to the United Kingdom NCP against DAS Air, a cargo airline operating out of hubs in Amsterdam, London, Dubai, Entebbe and Lagos. RAID alleged that DAS Air was involved in the transportation of coltan from the eastern DRC to the benefit of the Ugandan backed rebel group, Rally Congolese Democracy, operating in the eastern DRC. The case lingered on within the UK NCP process as the UK government considered its overall response to the DRC report. The matter generated increased attention in the media and among Members of Parliament. The NCP took up the DAS case in 2007 and issued a final statement in 2008. The statement reported that DAS Air "firmly denied that it had ever knowingly transported coltan sourced from the DRC, explaining they believed the coltan it flew out of Kigali originated in Kigali," 14 and that "they were merely contracted by the freight forwarders to transport the minerals; that all merchandise transported by DAS Air was customs-cleared before it was transported and DAS Air had not at any time been aware that any coltan transported by it originated from DRC." Moreover, DAS Air stated that "any enquiries the NCP has in regards to the consignors and consignees should be made to DAS Air's customer as DAS Air would not have that information," thereby acknowledging that it had made no efforts to investigate what it was transporting. ${ }^{15}$

One month after the UN Human Rights Council welcomed the Protect, Respect and Remedy Framework in June 2008, which the UK government supported, the UK NCP issued its final report, rejecting DAS Air's explanations regarding its lack of information about the source of the coltan. The NCP report stated that "flights recorded by the Porter Commission [established by Uganda to investigate Ugandan involvement] showing DAS Air flying between Entebbe and DRC illustrates that DAS Air should have had a clear understanding of the potential for the minerals to have been sourced from Eastern DRC. DAS Air clearly stated to the NCP that they did not question the source of the mineral that it transported, [and therefore] the NCP considers that DAS Air undertook insufficient due diligence on the supply chain."16 The NCP report cited several provisions of the 2000 OECD Guidelines. Interestingly, none of them include human rights due diligence. The implicit source for that concept was the newly adopted UN Framework. 


\section{Afrimex}

In 2007, the NGO Global Witness brought a case against Afrimex, a UK-based commodities trader that had also featured in the UN DRC report. In August 2008, the UK NCP applied a similar human rights due diligence argument to the Afrimex case as in the DAS case. Afrimex was accused of paying taxes to rebel forces in the DRC and practicing "insufficient due diligence on the supply chain, sourcing minerals from mines that use child and forced labor, who work under unacceptable health and safety practices." ${ }^{17}$ While Afrimex claimed that it was several steps removed from the mines, and that a "lack of an audit chain prevents Afrimex's materials from being traced back to the mine [where] they were sourced from," 18 the NCP determined that the links between UK-based Afrimex and DRC-based Societé Kotech and Socomi (family ties, overlapping directors who were also shareholder across the companies, among others) were sufficient for Afrimex to significantly influence those two companies. As a result, the NCP treated them as linked for the purposes of the complaint and urged Afrimex to use its influence over contracting parties and business partners throughout the supply chain. In this case, the UK NCP specifically referenced the UN Protect, Respect and Remedy Framework. In short, NCPs began to draw on the UN's work well before the UN Guiding Principles were fully developed or the OECD Guidelines revised.

\section{THE UNITED NATIONS GUIDING PRINCIPLES}

The operationalization of the Protect, Respect and Remedy Framework produced thirtyone Guiding Principles (GPs), each with commentary, elaborating the meaning of the foundational elements and their implications for law, policy, and practice. ${ }^{19}$ They represented six years of extensive research, nearly fifty consultations around the world, as well as pilot projects in different industry sectors and countries. The GPs had strong support from governments as well as the business community and many NGOs. In June 2011, the UN Human Rights Council unanimously "endorsed" the GPs, marking the first time that a UN body had ever endorsed a normative text that governments did not negotiate themselves. That endorsement made the GPs the authoritative global standard on the subject of business and human rights.

From the start, Ruggie pursued a strategy of implementation through distributed networks: that is, working with other international and national standard setting bodies, as well as additional stakeholder groups, including business itself, to achieve maximum coherence and alignment with the GPs, so as to leverage their influence on corporate conduct and generate greater scale effects. He collaborated closely with the OECD, which was discussing another revision of its own Guidelines as the GPs process drew to a close. As a result of this collaboration, the relevant parts of the updated OECD Guidelines are fully aligned with the UN Guiding Principles.

The 2011 OECD Guidelines incorporated two central elements from the GPs. First, it added a dedicated human rights chapter that replicates the GPs formulation of what it means for business to respect human rights, as well as stipulating the systems that companies need to put in place in order to meet their responsibility to respect human rights, centered on human rights due 
diligence processes. The corporate responsibility to respect human rights encompasses not only companies' own activities but also their business relationships. Second, the "General Policies" chapter of the Guidelines reiterates the GPs' formulation of the corporate responsibility to respect human rights, and it establishes a new due diligence requirement for all subjects covered by the Guidelines, except for the taxation provisions for which it was not considered appropriate. The OECD's NCP system thereby has become a potential venue to which human rights complaints regarding any and all internationally recognized rights, including workplace standards, can be brought against multinational enterprises operating in or from the 46 countries that adhere to the Guidelines, including several from emerging market countries. ${ }^{20}$ Thus, de facto the Guidelines now cover the majority of multinational enterprises and extend the due diligence requirements to their business relationships, including supply chains.

\section{PATTERNS OF COMPLAINTS (2000-2014)}

We now turn to a survey of cases examining overall patterns, beginning with a brief but necessary discussion of the methodology of case selection.

\section{METHODOLOGY OF CASE SELECTION}

According to the OECD, roughly 300 cases have been presented to the NCP system since 2001. These cases are logged into the OECD database in 12-month cycles that go from July to June of every calendar year. For this paper, we reviewed five such cycles spaced across a period of eleven years (2003-2014), which yielded 158 cases. The first three cycles reference the 2000 Guidelines whereas the latter two followed the Guidelines revision in 2011.

Table 1: Cycles Reviewed

\begin{tabular}{|c|c|}
\hline Guidelines of 2000 & Guidelines of 2011 \\
\hline July 2003-June 2004 (38 cases) & July 2012-June 2013 (38 cases) \\
\hline July 2007-June 2008 (16 cases) & July 2013-June 2014 (34) cases) \\
\hline July 2010-June 2011 (32 cases) & \\
\hline
\end{tabular}

However, there is no single data base of all complaints lodged with NCPs. Thus, we reviewed and drew on the three different databases:

- The OECD Specific instance Database is the OECD's official public online repository of cases. It covers complaints reported by NCPs that date back to 2000 when the mechanism was opened to civil society. However, prior to the 2011 revision of the Guidelines only complaints that NCPs accepted for consideration were reported into this official database. It does not include cases that NCPs declined to review because they did not consider them to fulfill the admissibility requirements. Moreover, some of the older cases had not 
yet been entered into the OECD database when we searched it in late 2014 and early $2015 .^{21}$

- OECD Watch is global network of NGOs that seeks to hold companies accountable for their adverse impacts around the globe. With more than 80 members in 45 countries, the OECD Watch Case Database tracks information on complaints brought to the OECD by a broad range of organizations from 2000 through the present day. But it includes only cases brought by civil society.

- The Trade Union Advisory Committee (TUAC), representing workers organizations has consultative status before the OECD and its various committees. Workers organizations have been one of the major users of the specific instance mechanism. The TUAC database contains information on 157 cases submitted by trade unions since 2000, which represents roughly half of all cases presented to date.

Thus, none of these databases has a comprehensive record of all cases submitted to NCPs. Moreover, each categorizes cases differently and some databases count the same submission to different NCPs as one single case while other count them as multiple instances. The official OECD Specific Instance Database contains the most cases overall (especially for more recent years), submitted from the broadest range of stakeholders. However, it often lacks detail or up-to-date information on cases, because it depends on information submitted by NCPs. The OECD Watch's Database contains more detailed information on specific cases, but only those presented by civil society organizations. Finally, $T U A C$ 's Database generally contains detailed and up-to-date information, but only on cases presented by workers organizations around labor issues.

To ensure the most comprehensive picture for this paper, information was cross-checked in all three databases to gain accuracy and the greatest detail possible. When the level of detail times varied or data was otherwise inconsistent (ranging from technical differences such as submission dates to substantive differences such as the current status of a case), additional research from supplementary sources was conducted wherever possible to corroborate the information. As a result, much of the data used in this paper was reached through an iterative process of clarification and consolidation of information.

Finally, in some instances NCPs chose to either split one submission into several cases (for instance, if one submission involved violations in several countries NCPs might have split the case among them, with each NCP leading on one piece). In other instances, NCPs chose to consolidate several submissions into one (if complainants submitted several cases around the same issue, the NCPs might have treated the submissions as one case, with a single NCP in the lead). In these situations we chose to treat cases according to the NCPs' decision because that allowed us to track the outcome of cases in a more consistent manner. This also explains any discrepancy in overall numbers of cases compared to the three databases. 


\section{OVERALL PATTERNS}

Figure 1 presents a graphic overview of all cases submitted from 2000 to 2014. The increase from 2002-2003 through 2003-2004 is partially due to the previously discussed UN investigation into the DRC. This brought the OECD Guidelines into the spotlight and led NGOs to submit several DRC cases to the NCP system, which account for at least twelve out of the thirty-eight cases identified in the June 2003 - June 2004 cycle alone. The 2004-2005 cycle saw an increase due to trade union cases; the increase recorded in 2010 is addressed in a subsequent section.

\section{Figure 1: Total Cases Submitted to the OECD (2000-2014)}

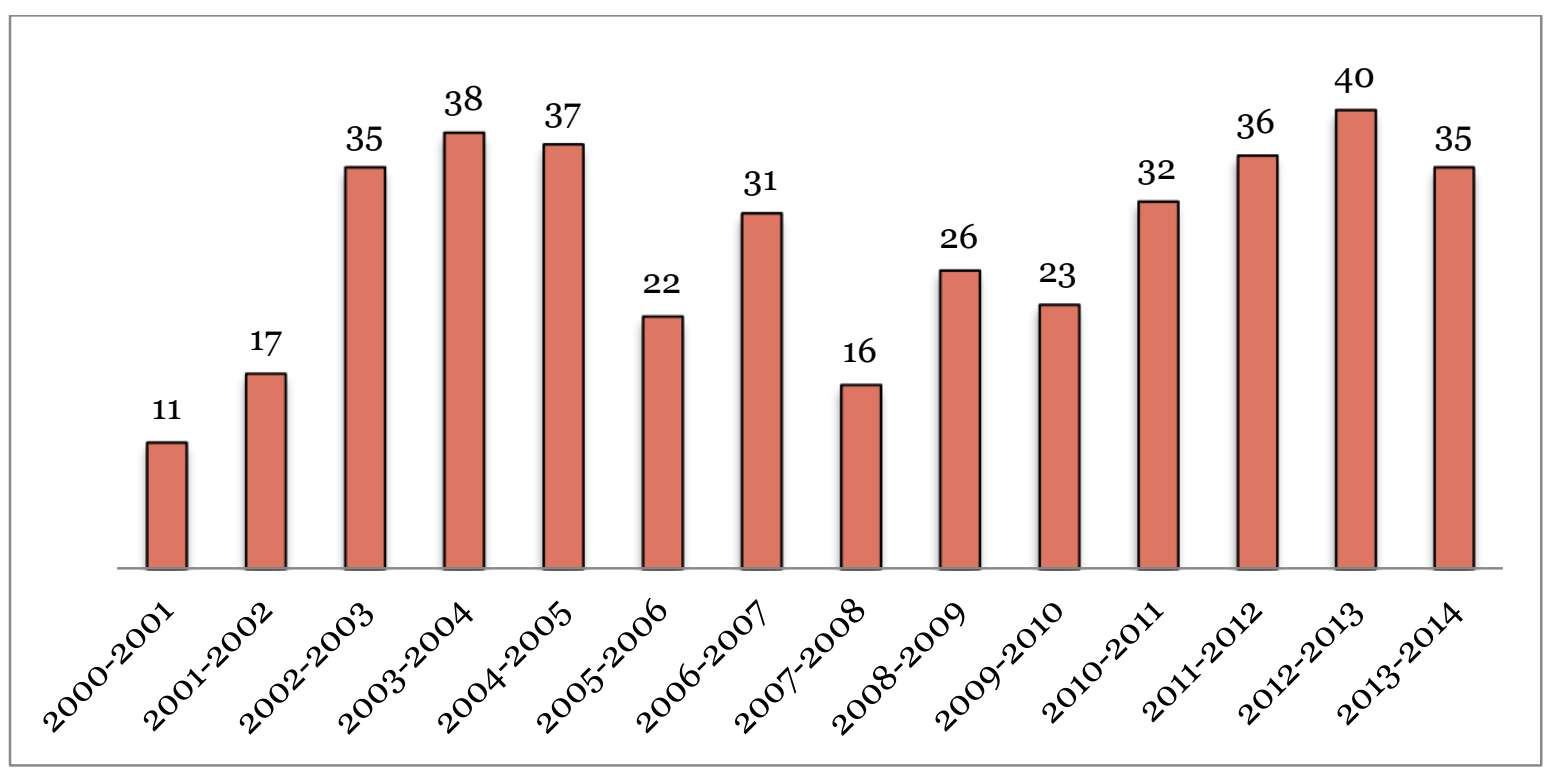

Source: Authors' calculation per case consolidation in the OECD, OECD Watch and TUAC databases.

\section{ADMISSIBILITY}

Figure 2 presents an overview of cases that NCPs decided to consider on their merits, as opposed to rejecting them outright. We coded three categories: accepted, rejected, and pendingwhere pending refers to NCPs not yet having decided whether to consider the case. Given the limited amount of information in the databases for earlier years, our analysis indicates that it is not known for certain in 37\% of the cases whether complaints in the 2003-2004 cycle had ever been formally admitted for review by an NCP. The subsequent cycles indicate admittance rates between 53\%-69\%. The admissibility rate is lower in the most recent cycle (2013-2014) presumably because in most of the cases no determination has yet been made on admissibility. This is consistent with past patterns of the time it takes for such decisions to be made. 
Figure 2: Admissibility of Cases

2003-2004

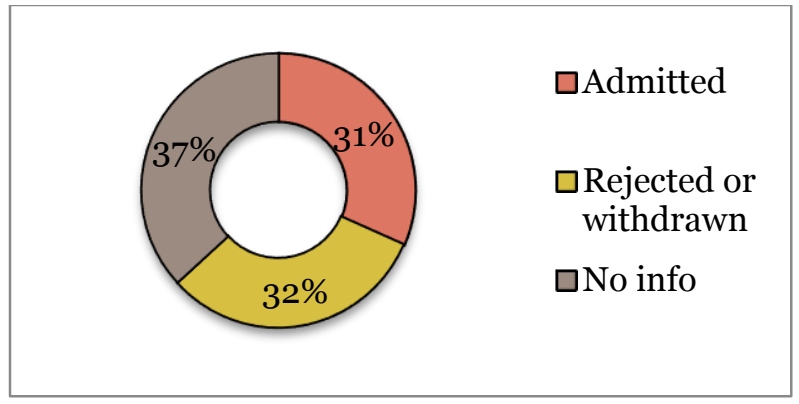

2010-2011

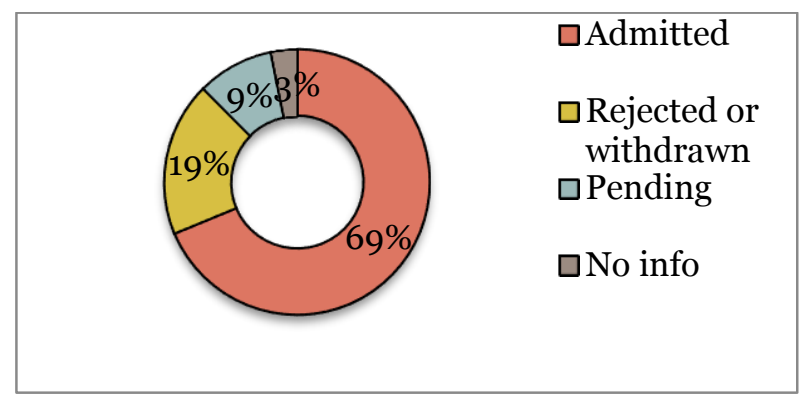

2007-2008

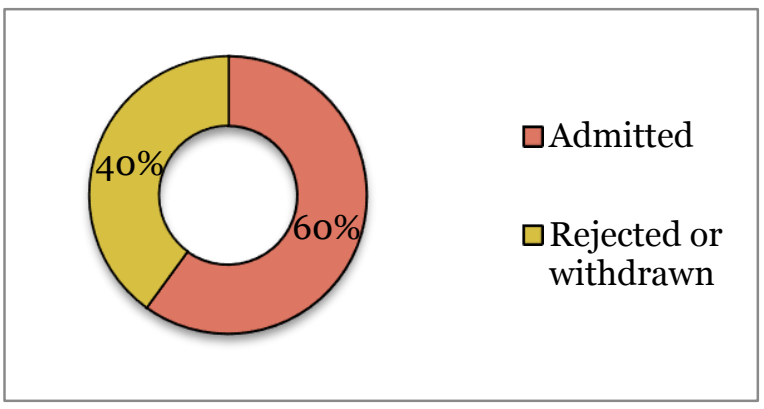

2012-2013

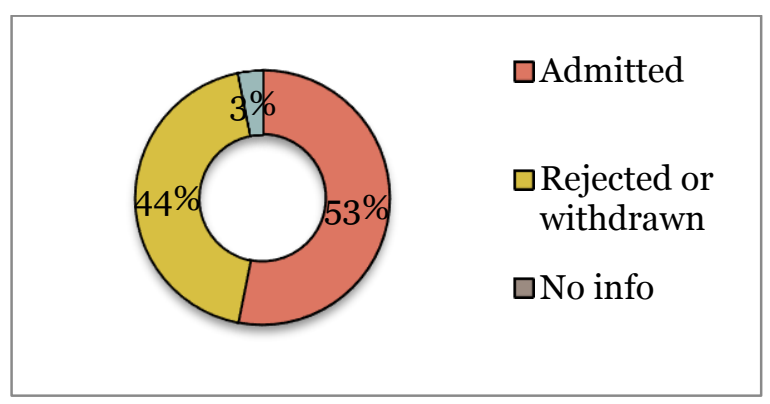

2013-2014

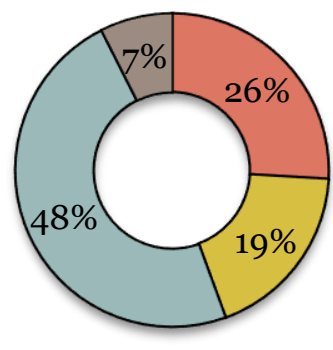

口Admitted

$\square$ Rejected or withdrawn

$\square$ Pending

$\square$ No info

\section{HOST AND HOME COUNTRIES}

One reason for reviewing the Guidelines in 2000 is that the landscape of international investment and multinational enterprises had changed dramatically in the previous decade. NonOECD countries were attracting more foreign investment, and enterprises from non-adhering countries were gaining more relevance within the global arena. ${ }^{22}$ One way to track this is to compare the geographical distribution of host countries (where operations take place) to home countries (where enterprises are headquartered). 
Figure 3 demonstrates that there has been a diversification of regional distribution of host countries. In the first cycle of 2003-2004 no cases from North America, Oceania and Europe were submitted. This begins to change in the following cycle. In the last cycle analyzed all regions are represented and roughly half of cases taking place in Asia and Europe.

Figure 3: Host Country Regional Distribution

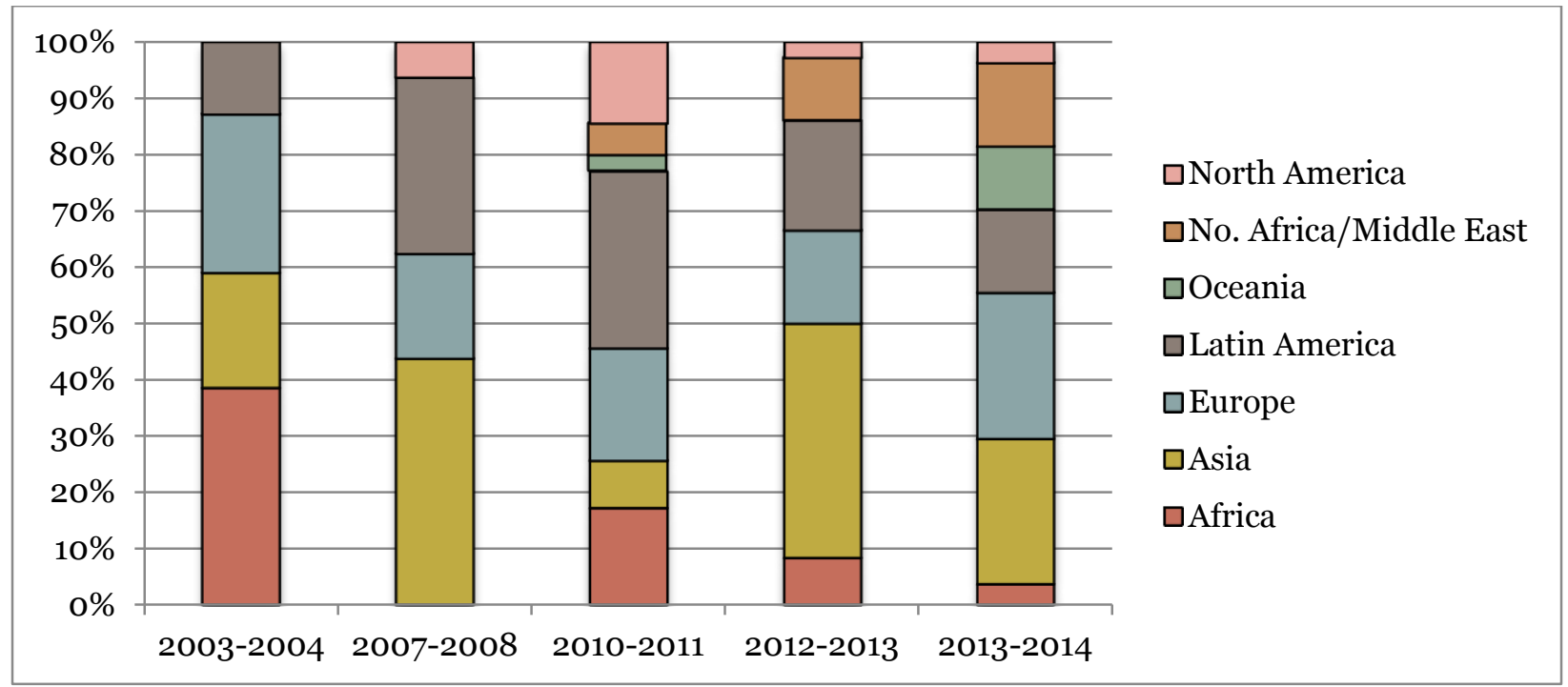

The record of home countries involved in cases submitted to the NCP system is more consistent and less surprising. Figure 4 demonstrates that the overwhelming majority of MNEs involved in submissions were based in advanced and high-income economies, especially in Europe; this number increased under the 2011 Guidelines, especially in the 2013-2014 cycle.

Figure 4: Home Countries Regional Distribution

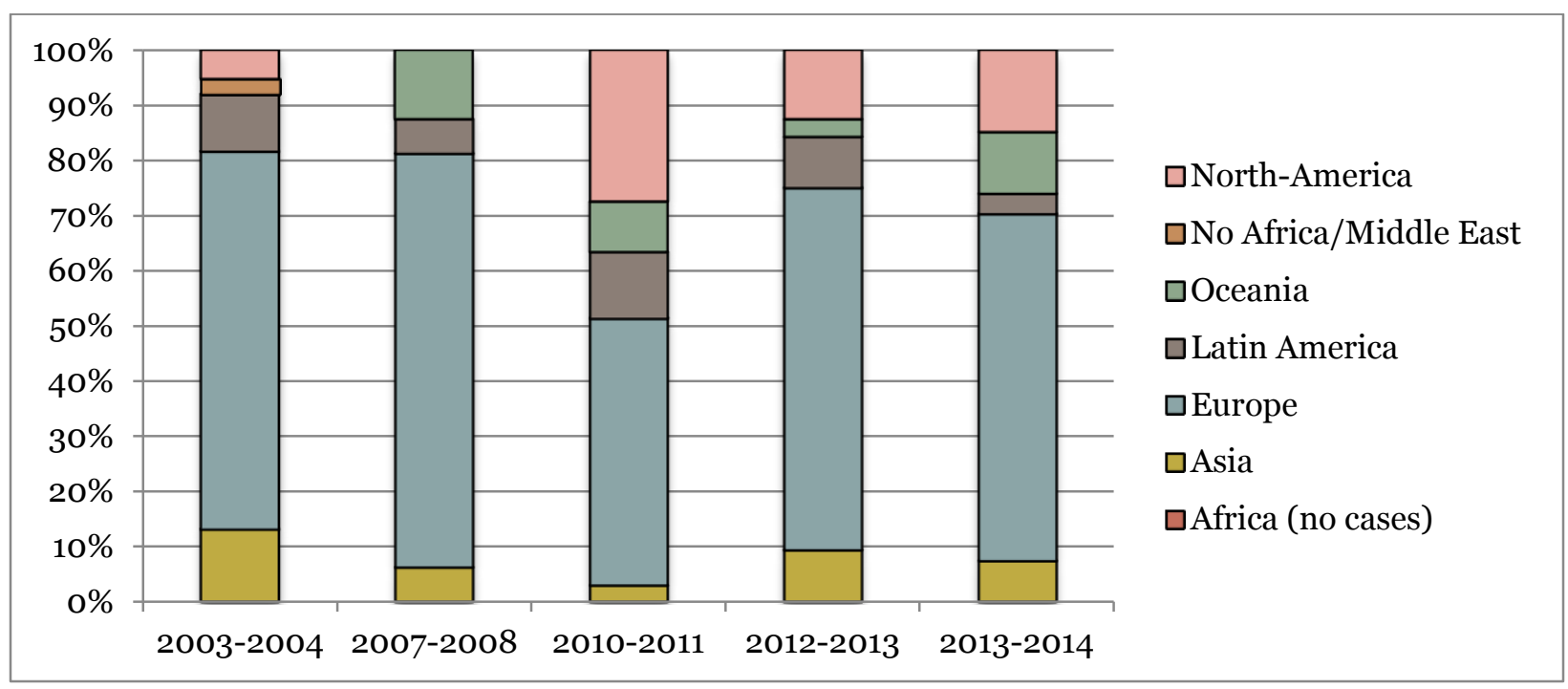

Figure 5 provides the same information for home and host countries over the five cycles (excluding countries with fewer than two cases to keep the Figure at a manageable size). 
Figure 5: Host/Home Country Distribution of Cases

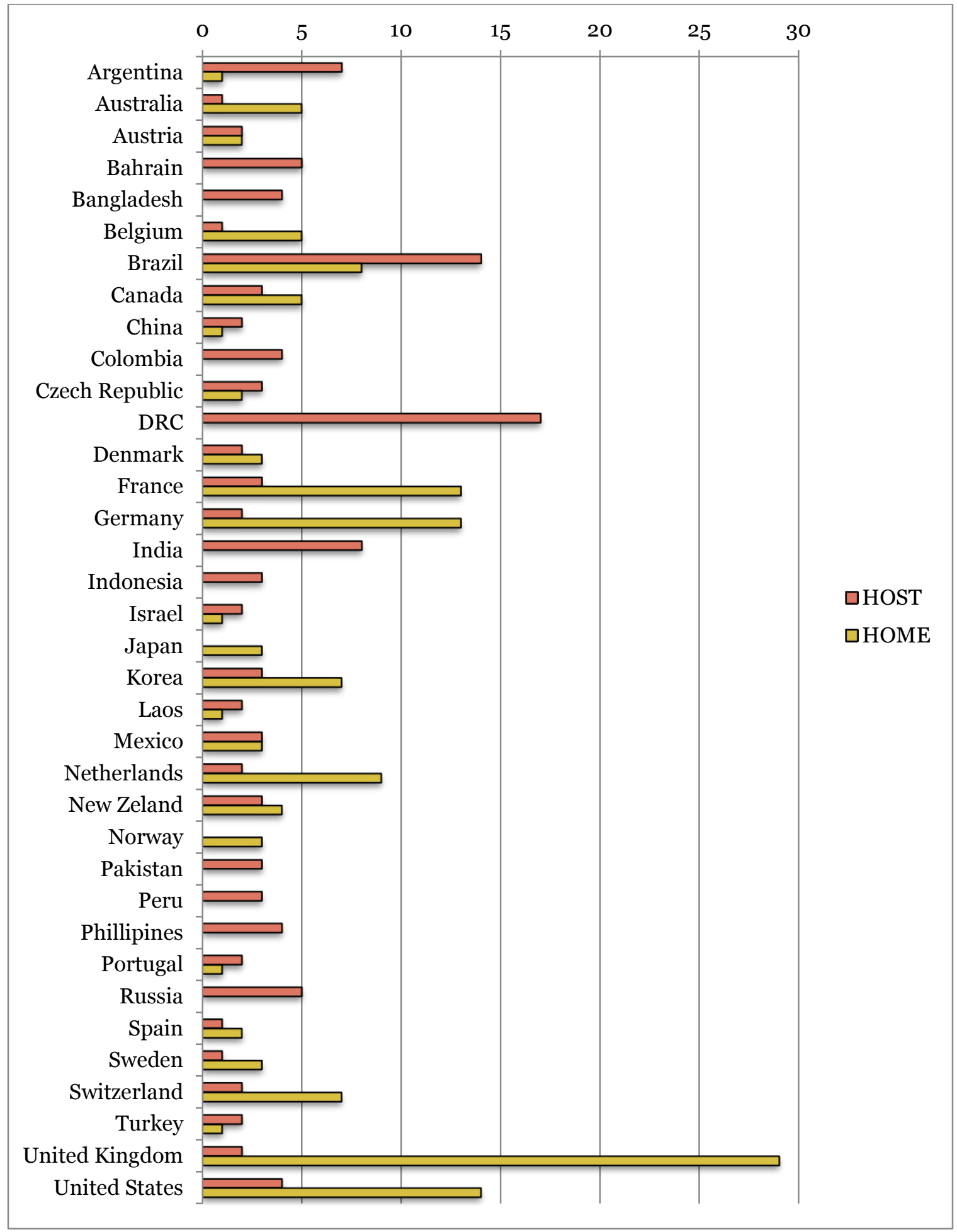

Note: This table indicates the distribution of cases against companies for conduct in their respective home and host countries, not to which NCP a case was brought. 
The home countries with the highest number of cases throughout the five cycles reviewed were the UK (29), USA (14), France and Germany (13), Netherlands (9), and Brazil (8). The host countries with the highest number of cases were DRC (17), Brazil (14), India (8), and Argentina (7). Thus, while investment trends have changed, cases submitted to NCPs largely continue to reflect patterns very similar to the past: host countries (where operations take place) in the global south and emerging markets, and home countries (where MNEs are headquartered) tending to be in the global north. Brazil is the only country that has a significant number of cases both as a home and host state: in 9 instances it was the home of MNEs against which a complaint was lodged with an NCP, and in 14 it was the host state. It is worth noting that the high number of cases for some countries may be related not only to the actual distribution of corporate-related human rights harm by companies headquartered in those jurisdictions but also to greater stakeholder confidence in that country's NCP process.

\section{THE SUBSTANCE OF COMPLAINTS}

Historically, the human rights issues the NCP system dealt with were largely confined to workplace complaints, referencing ILO standards. Trade unions were one of the major users of the NCP system and Chapter IV of the 2000 Guidelines, "Employment and Industrial Relations." In contrast, in the 2000 Guidelines broader human rights issues were mentioned only briefly in Chapter II, entitled "General Policies," stating that companies should "respect human rights not only in their dealings with employees, but also with respect to others affected by their activities, in a manner that is consistent with host governments' international obligations and commitments." 23 This significantly limited the scope of human rights cases that could be brought to NCPs.

Figure 6 reflects which provisions of the 2000 Guidelines complainants invoked most frequently. Provisions in Chapter IV on "Employment and Industrial Relations" were cited 104 times, compared to 96 references to Chapter II on "General Policies," which covers a broad set of issues, only one of which is harm to human rights (beyond workplace issues) that the host country has recognized through treaty ratification. Although labor was the top issue addressed under the 2000 Guidelines, the number of citations of provisions under Chapter II "General Policies" and Chapter V "Environment" increased during the last cycle under which the Guidelines applied (2010-2011). At that time, another Guidelines revision was already under discussion, which might have prompted civil society organizations to submit cases as a way to influence the debates around the revisions. 
Figure 6: Provisions most cited under the 2000 Guidelines

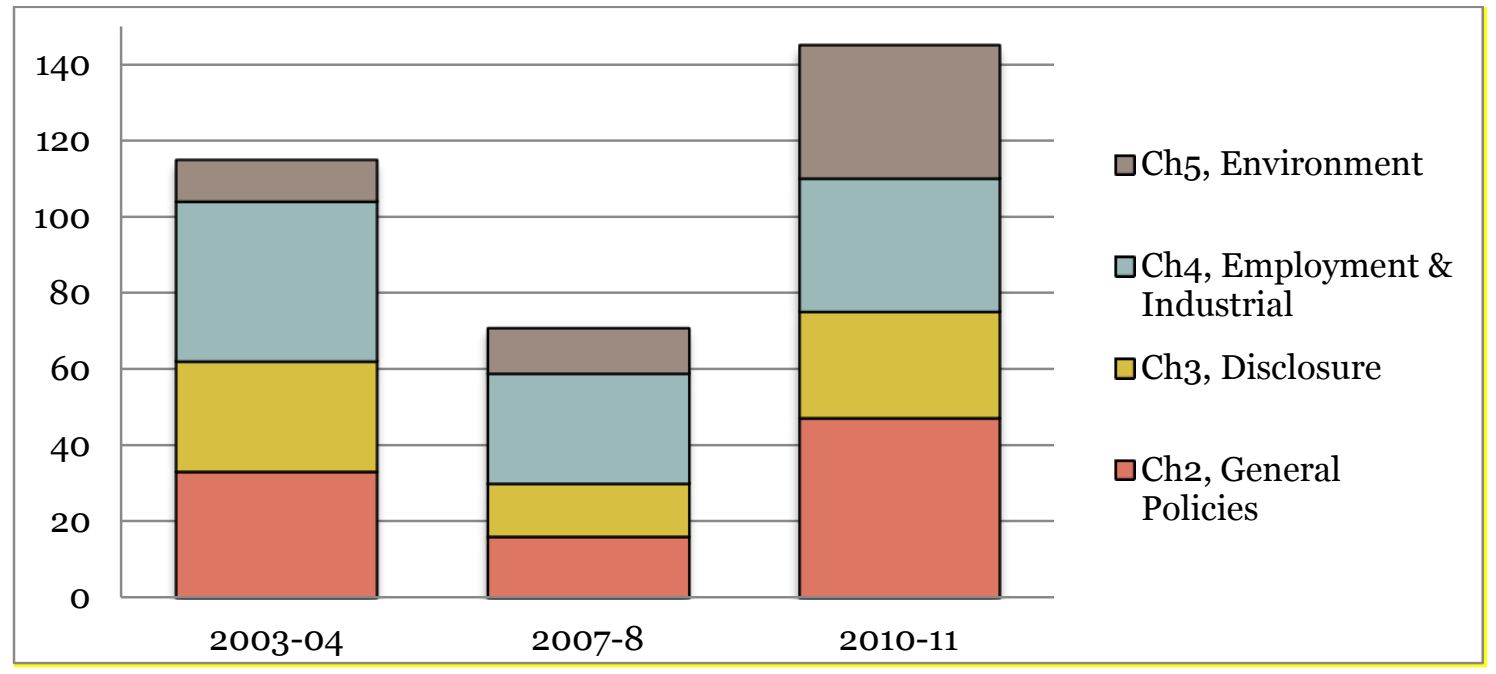

III. HUMAN RIGHTS CASES UNDER THE 2011 GUIDELINES

Public discussion about a possible revision of the Guidelines began at the 2009 Annual Meeting of NCPs and the OECD Council Meeting at Ministerial level, which welcomed "further consultation on the updating of the OECD Guidelines to increase their relevance and clarify private sector responsibilities." 24 In April 2010, the OECD officially announced that the Guidelines would be updated. The terms of reference for the revision stated that the new version should provide more guidance to assist companies to "identify, prevent and remedy negative human rights impacts which may result from their operations," including a separate human rights chapter "drawing, in particular, on the work of the UNSRSG."25

A historical review of the number of cases submitted to the NCPs shows that a general increase in cases coincides with any Guidelines revision. The 2000 Guidelines were last applied to the 2010-2011 cycle and the current version of the Guidelines came into effect for NCPs' casework in the 2011- 2012 cycle. A look back at Figure 1 will show the expected bumps. But it also shows that the high number of submissions during the post-2011 cycles is comparable only to the years (2002-2005) when a series of DRC cases were referred to the OECD.

The issue we want to turn to now is to see what the impact has been of the new human rights additions to the 2011 Guidelines. Although these are still early days, it appears that there may be five such impacts to date: more human rights cases than other types of complaints; a greater diversity of human rights cases than in the past; a diversification of industries against which complaints are brought; the growing role of the Guidelines' due diligence provisions; and a higher admissibility rate for human rights cases than for others. 


\section{GREATER NUMBER AND INCREASED DIVERSITY OF HUMAN RIGHTS CASES}

The first point is easily demonstrated. In the 2012-2013 cycle 32 of 38 complaints submitted addressed human rights issues; in the 2013-2014 cycle it was 27 of 34 cases (the latter overall number may increase as some of these cases are likely still being processed).

The expanded scope of human rights cases follows virtually by definition, because under the Guidelines they now include all internationally recognized rights, not merely those a host government has ratified. Thus, while labor rights cases continue to be the single largest category, their proportion of total rights-related complaints has dropped from 40 percent in 2003-2004 to 30 percent in the most recent cycle. In turn, issues related to community consultations, impeding or destroying sources of livelihood, health and housing, as well as the security of the person and privacy rights, have increased.

A similar diversification is found in the industry sectors involved. Extractives and manufacturing have always dominated. But as Figure 6 shows, cases involving the extractives have declined whereas manufacturing held relatively steady - the latter undoubtedly due to the new Guidelines provision, following the UN Guiding Principles, that extended their scope not only to operating companies but also to their business relationships, including supply chains. For similar reasons, the number of cases involving financial institutions has increased.

Figure 6: Industry Sector

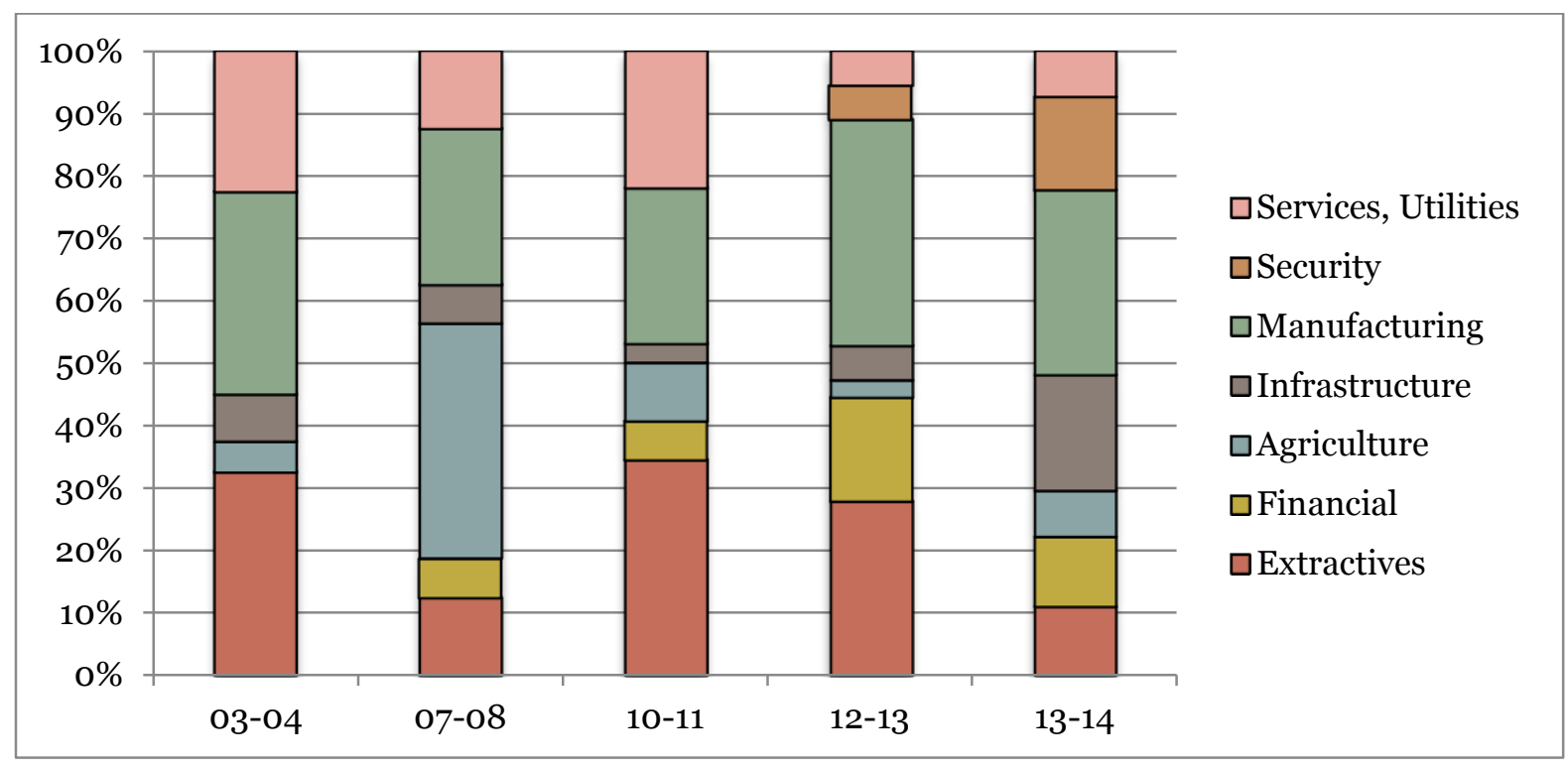

Note: A few cases involve more than one industry. 


\section{DUE DILIGENCE PROVISIONS}

The UN Guiding Principles and the 2011 OECD Guidelines stipulate not only what business should do in relation to human rights, but also in broad terms how they should do it. The "what" consists of avoiding causing or contributing to adverse human rights impacts, including through their business relationships, and to address such impacts where they occur. The "how" lays out a human rights due diligence process, which includes assessing actual and potential human rights impacts, integrating and acting upon the findings, tracking responses, and communicating how impacts are addressed especially to those who are most directly affected.

As already noted, human rights (other than labor standards) appear twice in the 2011 Guidelines: in Chapter II ("General Policies") and in a new Chapter IV ("Human Rights") elaborating on the specific human rights due diligence requirement. We have included a detailed explication of these provisions and their invocation in Appendix I. Appendix II summarizes some illustrative cases. For now, suffice it to say that the two top human rights provisions cited by complainants relate to due diligence. The provision referenced most often stipulates that enterprises should "avoid causing or contributing to adverse human rights impacts and address such impacts when they occur" (Chapter IV of the Guidelines, paragraph 2), and the second most frequent states that MNEs should "carry out human rights due diligence as appropriate to their size, the nature and context of operations and the severity of the risks of adverse human rights impacts" (Chapter IV, paragraph 5).

A recent example will help illustrate how these provisions are being used. It involved Americans for Democracy and Human Rights in Bahrain (ADHRB) vs. Formula One Management Ltd. In May 2014 the ADHRB filed a case with the UK NCP concerning four companies that it identified as being involved in managing Formula One Grand Prix in Bahrain. The pro-democracy NGO claimed that holding the race in Bahrain sent a message to the international community that it ignored ongoing human rights abuses in that country, and that the race itself had increased human rights violations in light of the response by law enforcement officials to protests associated with it.

Five months later, the UK NCP stated that "the fact that the companies promote a high profile event that attracts protests does not itself link them to alleged abuses of protestors. As no other information is offered, the UK NCP rejects the issues raised relating to the companies' obligations to avoid or address impacts." ${ }^{26}$ However, the NCP did accept parts of the complaint against Formula One World Championship Limited and Formula One Management Limited, especially those related to appropriate due diligence and stakeholder engagement.

Within this context, the UK NCP offered to mediate a resolution of the case. As a result, in April 2015 a joint statement was issued in which the Formula One Group committed to adopt a formal human rights policy. This is significant because it requires them "to develop and implement a due diligence policy in which Formula One analyzes and takes steps to mitigate any human rights impact that its activities may have on a host country." The Formula One statement also said that "where domestic laws and regulations conflict with internationally recognised human rights, the Formula One Group will seek ways to honour them to the fullest extent which 
does not place them in violation of domestic law."27 This follows precisely the language used in the UN Guiding Principles and the OECD Guidelines of 2011.

In sum, the Guidelines' due diligence provisions provide companies with high level guidance on what they need to do to address the risk of contributing to human rights harm. At the same time, it gives affected individuals and communities a "hook" to lodge NCP complaints when companies not are complying with the "what" and the "how" of respecting human rights.

\section{ADMISSIBILITY OF HUMAN RIGHTS CASES}

In addition to a change in the substance of human rights cases submitted to the NCP system, Figure 7 indicates that in the most recent cycles, complaints involving human rights have had a greater chance of being admitted to the NCP system than complaints referencing other Guidelines provisions. In the 2012-2013 cycle 53 percent of human rights-related cases were admitted. No non-human rights cases were known to have been admitted and one third of such cases are still pending a decision on admissibility. For the 2013-2014 cycle 26 percent of human rights cases have been admitted while another 50 percent are still pending. Of non-human rights cases, half have already been rejected.

Figure 7: Admissibility of Human Rights Cases under the 2011 Guidelines

2012-2013 (HR Cases)

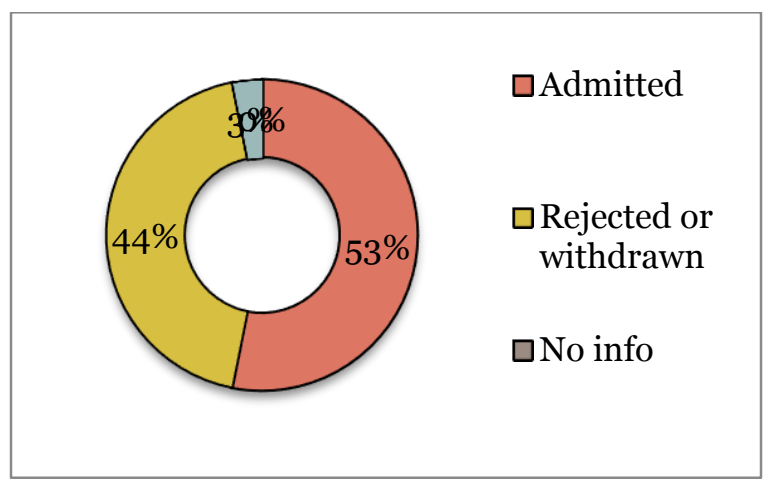

2012-2013 (Non-HR Cases)

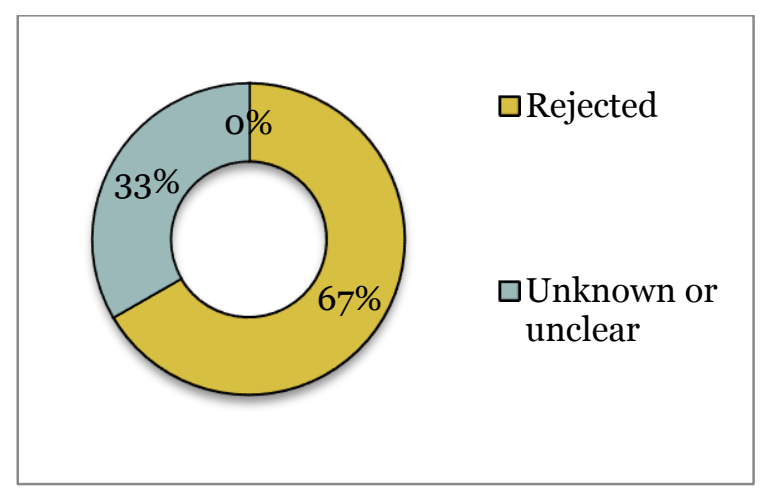


2013-2014 (HR Cases)

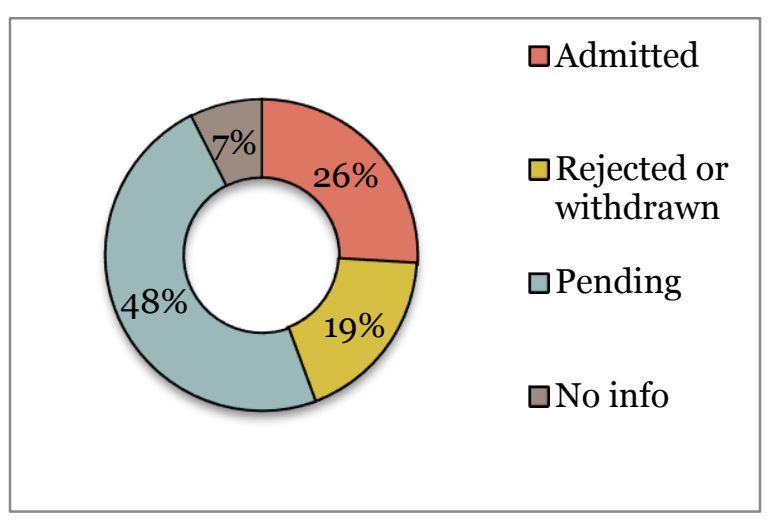

2013-2014 (Non-HR Cases)

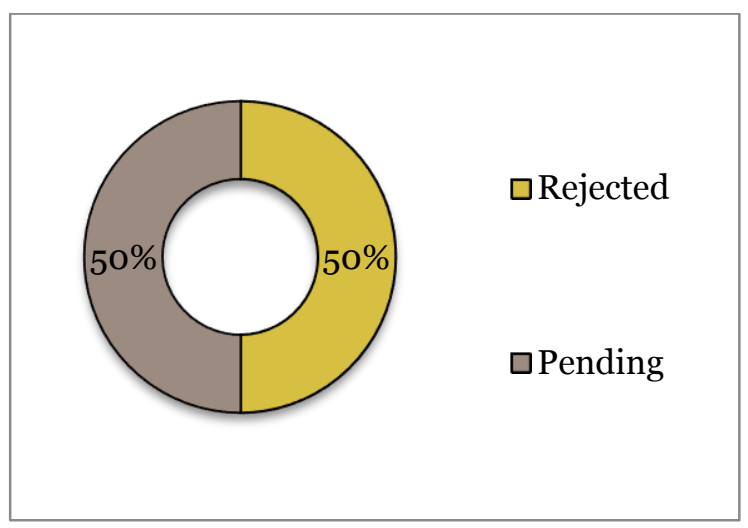

\section{NEXT STEPS: THE EXTENDED ENTERPRISE AND ITS ENABLERS}

From the start, the OECD Guidelines have been an integral part of the Declaration on International Investment and Multinational Enterprises. In recognition of globalizing supply chains in the 1990's, one of the changes introduced in the Guidelines' revision in 2000 was an addition that MNEs should "encourage, where practicable, business partners, including suppliers and sub-contractors, to apply principles of corporate conduct compatible with the Guidelines." 28 Because NCPs subsequently applied different standards to supply chain cases, the OECD Committee on Investment and Multinational Enterprises issued an opinion in 2003 that the Guidelines should also apply to "investment-like relationships" on a case-by-case basis. ${ }^{29}$ But this still could be interpreted as requiring a direct equity stake in the supplier, potentially ruling out global brands and retailers whose relationship with suppliers is purely contractual. OECD Watch's assessment of the NCP system in 2010 indicated that one of the most common reasons given by NCPs for rejecting NGO cases included the lack of an "investment nexus" between the MNE facing the complaint and the entity that committed the alleged violation. ${ }^{30}$

The updated Guidelines of 2011 expanded their scope, stating that MNEs should avoid causing or contributing to adverse impacts on the social, environmental and other interests related to the Guidelines, not only through their own activities but also through their business relationships. The text explicitly states that the "Guidelines concern those adverse impacts that are either caused or contributed to by the enterprise, or are directly linked to their operations, products or services by a business relationship." ${ }^{11}$ The latter is defined as "relationships with business partners, entities in the supply chain and any other non-State or State entities directly linked to its business operations, products or services." ${ }^{32}$ Therefore, MNEs should carry out riskbased due diligence efforts to identify, prevent and mitigate adverse impacts throughout its extended enterprise and business relationships. That issue is now settled principle. 
Although supply chain due diligence was incorporated into the Guidelines of 2011, the role of minority shareholders subsequently arose as a question that had not been specifically addressed. The case of Pohang Iron and Steel Enterprise (POSCO), the fourth largest global steel producer, triggered it. In October 2012 a coalition of NGOs from South Korea, the Netherlands and Norway (Lok Shakti Abhiyan, South Korean Trans National Corporations Watch, Fair Green and Global Alliance, and the Forum for Environment and Development) filed complaints with their respective NCPs regarding POSCO's proposed iron mine, steel plant and related infrastructure such as a port and roads in Odisha, India.

The complaint was filed against POSCO and its joint venture POSCO India Private Limited. The coalition of NGOs maintained that POSCO did not conduct human rights and environmental due diligence, including adequately consulting with communities about actual and potential impacts. Therefore, POSCO was in no position to "seek to prevent and mitigate human rights abuses directly linked to their operations and exercise their leverage to protect human rights" ${ }^{33}$ _ including of the 20,000 people expected to be economically and physically displaced. ${ }^{34}$

In addition to targeting POSCO and its joint venture partner, the NGOs also sought to hold responsible several project investors. One was the Dutch Pension Fund (ABP) and its pension funds asset manager, All Pension Group (APG). ${ }^{35}$ The other was the Norwegian Government Pension Fund Global (GPFG), the world's largest sovereign wealth fund, and its operational fund manager, Norges Bank [Norway's Central Bank] Investment Management $(\mathrm{NBIM})^{36}$ — which is a signatory to a 2011 investor statement supporting the adoption of the United Nations Guiding Principles on Business and Human Rights. The complaint against them stated that as investors they should "seek to prevent or mitigate adverse impacts directly linked to their operations through their financial relationships with POSCO." 37 ABP reportedly had shares in POSCO worth approximately $€ 17$ million, ${ }^{38}$ and as of December 2012 NBIM's holdings in POSCO amounted to 1,420 million NOK, representing a $0.9 \%$ of ownership share. ${ }^{39}$ Clearly this was new territory.

NBIM asserted that the OECD Guidelines did not apply to minority shareholders and essentially ignored the complaint. In May 2013 the Norwegian NCP issued a final statement drawing not only on the OECD Guidelines, but also on the UN Guiding Principles as a source document, as well as a letter the NCP had requested from the UN Office of the High Commissioner for Human Rights on the applicability of the GPs to minority shareholders. ${ }^{40} \mathrm{On}$ that basis, the Norwegian NCP concluded that the Guidelines do apply to all types of business enterprises and relationships, and that the Guidelines' Commentary defines business relationship to include "relationships with business partners, entities in the supply chain and any other nonState or State entity directly linked to its business operations, products or services." 41 The NCP added that "the Guidelines do not make any exception for minority shareholders." 42 Furthermore, the NCP stated that the size or percentage of the shareholding is not a determining factor in the attribution of responsibility, and that "although the [Norwegian Government Pension] Fund's equity investment in any single enterprise is on average one per cent and does not often exceed five per cent, this can nonetheless be a significantly large investment in monetary terms."43 
Accordingly, the Norwegian NCP concluded that an investor is "expected to seek to prevent or mitigate human rights risks identified in relation to shareholdings - including minority shareholdings." 44 The NCP also drew upon the UN Guiding Principles to explain that "the appropriate action in response to the identified risk depends on the degree of [a business'] leverage, where a number of options would be considered with a view to use or enhance leverage, to effect change in terms of ending harmful practice and mitigating risks of human rights abuse." 45 The NCP stressed the importance of collaborating with other investors in order to increase their ability to conduct investigations into allegations and/or to exercise influence to over POSCO to address human rights issues, stressing the need for investors to proactively engage in due diligence and find ways to influence a company's human rights practices.

Similarly, the Dutch NCP issued final statement confirming that the OECD Guidelines apply to minority shareholders, and both ABP and APG committed to exercise their leverage in order to bring POSCOs business practices in line with international standards. Ultimately, its final statement concluded that "investors and other financial institutions have a responsibility to exert influence where possible on companies they invest in to help prevent or mitigate possible adverse impacts on these companies' operations." ${ }^{46}$ Both the Norwegian and Dutch NCP's statements established what may become an important precedent for future cases regarding financial institutions and set the bar for what is expected from minority shareholders.

The POSCO case did not quite end there. While Norway's Government Pension Fund Global fund manager initially had ignored Norway's NCP, once the final statement was issued the Norwegian Finance Ministry sought a clarification from the OECD Working Party on Responsible Business Conduct, a subsidiary body of the Investment Committee composed of representatives of all countries adhering to the Guidelines, regarding the applicability of the Guidelines to financial institutions and to minority shareholders. The Working Party conducted extensive consultations, not only among its own members but also with outside experts. It issued several reports on the subject of sovereign wealth funds, financial institutions in general, and minority shareholders. ${ }^{47}$ The Working Party's conclusion in these reports was that the relevant issue was not whether the Guidelines apply to such entities, but precisely how-since such entities do differ from front-line operating companies. Thus, not only did the Working Party reaffirm the applicability of the Guidelines to all business enterprises, with no exception. It also established what could become an important interpretive function to clarify the many questions that surely will arise in the future regarding the application of the Guidelines to specific industry circumstances and operating contexts.

\section{CONCLUSION AND RECOMMENDATIONS}

This paper has documented the trajectory of the OECD "specific instances" mechanism - its complaints procedure - since 2000, with a particular focus on how the new human rights provisions introduced in 2011 have affected and may continue to affect that trajectory. The admittedly limited post-2011 data suggests five impacts: more human rights cases than other types of complaints; a greater diversity of human rights cases than in the past; a 
diversification of industries against which complaints are brought; the growing role of the Guidelines' new human rights due diligence provisions; and a higher admissibility rate for human rights cases than for others. The discussion indicates considerable normative innovation since 2000. It also suggests fruitful future developments regarding the applicability of the Guidelines to various types of financial institutions and minority shareholders, as well as a potential interpretive function by the OECD Investment Committee supported by its Working Party on Responsible Business Conduct to assist in the inevitable development of more granular guidance for specific industry sectors and operating contexts. Indeed, that process has already begun. The OECD Due Diligence Guidance for Responsible Supply Chains of Minerals from Conflict Affected and High-Risk Areas has become a de facto international standard. ${ }^{48}$ The Working Party is also developing similar guidance for the agricultural, garment and footwear sectors, and will soon turn to the financial sector.

Moreover, while complainants often criticize the NCP system for taking a long time to decide on cases - and many do drag on for extended periods of time - the fact is that court proceedings and quasi-judicial international and regional systems can take even longer. The NCP system's unique focus on mediation provides those affected by human rights harms a potentially simpler and relatively quicker alternative for the resolution of certain disputes that either do not require, or for which the complainants prefer not to pursue, judicial or quasi-judicial routes. It also can offer those at risk of violations an avenue to file a formal international complaint to stop a potentially harmful practice from moving forward, as was the case with the WWF-SOCO agreement described in Annex II, which represents the first time a company agreed to halt operations during NCP-facilitated mediation. But what remains generally unclear from the available documentation is what if any actual remedy complainants receive or what changes in company policies and practices as a result of NCP findings and/or mediation.

Thus, many implementation challenges remain - and unfortunately most of them are not fundamentally new. To begin with, according to the OECD database, 14 NCPs have never received a single complaint, and several only one. It is simply implausible to assume that this in every case reflects the absence of breaches of the Guidelines; it is far more likely that the NCPs in question are invisible or unresponsive to potential complainants. While the NCP system is designed to be decentralized, every club has basic rules to which participants must adhere. The OECD Guidelines are no exception. Indeed, promoting awareness of them is a legal obligation undertaken by governments. Therefore, minimum performance standards for NCPs and peer learning from the innovators among them should become a procedural requirement. The OECD Guidelines represent a "brand" of good corporate conduct. That brand must be protected by all OECD members and adhering states if the Guidelines and the NCP system are to be taken seriously in this space in the future. Moreover, it is by now well established that the less that governments do, the greater will be the pressure on and possible community conflicts with the businesses in question. The separate Procedural Guidelines adopted in 2011 in fact address this issue, providing for the Investment Committee to "consider a substantiated submission by an adhering country, an advisory body or OECD Watch on whether an NCP is fulfilling its 
responsibilities with regard to its handling of specific instances." 49 But this provision has yet to be invoked.

Furthermore, with one single exception, no government has publicly stated that noncooperation by a company with an NCP or a negative finding against a company will have any material consequences imposed by a government. Forty years of pure voluntarism should be a long enough period of time to conclude that it cannot be counted on to do the job by itself. The one exception is Canada, which in November 2014 announced a CSR new strategy, "Doing Business the Canadian Way: A Strategy to Advance Corporate Social Responsibility in Canada's Extractive Sector Abroad." The strategy references both the Guidelines and the UN Guiding Principles. Here is the strategy's key new element: "As a penalty for companies that do not embody CSR best practices and refuse to participate in the CSR Counsellor's Office or NCP dispute resolution, Government of Canada support in foreign markets will be withdrawn." 50 Canada's NCP has already issued one final statement based on the new strategy, specifically concluding: "As the Company did not respond to the NCP's offer of its good offices, the Company's non-participation in the process will be taken into consideration in any application by the Company for enhanced advocacy support from the Trade Commissioner Service and/or Export Development Canada (EDC) financial services, should they be made." ${ }^{51}$ Surely this example deserves to be emulated more widely within the NCP community.

That brings us to the last point: the relationship between the OECD Guidelines and the OECD Common Approaches regarding Export Credit Agencies (ECAs). Export credit is an obvious governmental source of leverage for compliance with the Guidelines. As things currently stand, the Guidelines embody higher standards than the Common Approaches. This is another way of saying that governments are in the untenable position of asking more of business than they are demanding of themselves. The relationship between the Guidelines and Common Approaches has been a long-standing doctrinal debate in the OECD. Recently, some OECD members sought to have the Export Credit Group to modify the Common Approaches, incorporate human rights due diligence and thereby aligning the Common Approaches with the Guidelines and the UNGPs. ${ }^{52}$ The proposal gained no traction. One ECA repeated an argument it has made many times before that the Guidelines and UN GPs do not apply to it because it is not an official body but a commercial entity-missing the irony that business is precisely to whom the OECD Guidelines and Pillar 2 of the UN GPs are addressed. ${ }^{53}$ Thus, for the moment, policy incoherence within governments in this space remains intact, with potentially serious adverse consequences for the credibility of the NCP system and the Common Approaches alike.

In sum, considerable normative innovation has taken place in the Guidelines-based system over the years, and that is to be applauded. But now the time has come to improve on its implementation modalities, for which excellent precedents, good practices, and emerging possibilities already exist. 


\section{APPENDIX I}

Human Rights related Provisions under the Guidelines Chapter II ("General Principles")

2. Enterprises should respect the internationally recognised human rights of those affected by their activities

5. Refrain from seeking or accepting exemptions not contemplated in the statutory or regulatory framework related to human rights, environmental, health, safety, labour, taxation, financial incentives, or other issues.

10. Carry out risk-based due diligence, for example by incorporating it into their enterprise risk management systems, to identify, prevent and mitigate actual and potential adverse impacts as described in paragraphs 11 and 12, and account for how these impacts are addressed. The nature and extent of due diligence depend on the circumstances of a particular situation.

11. Avoid causing or contributing to adverse impacts on matters covered by the Guidelines, through their own activities, and address such impacts when they occur.

12. Seek to prevent or mitigate an adverse impact where they have not contributed to that impact, when the impact is nevertheless directly linked to their operations, products or services by a business relationship. This is not intended to shift responsibility from the entity causing an adverse impact to the enterprise with which it has a business relationship.

13. (...) Encourage, where practicable, business partners, including suppliers and subcontractors, to apply principles of responsible business conduct compatible with the Guidelines.

14. Engage with relevant stakeholders in order to provide meaningful opportunities for their views to be taken into account in relation to planning and decision making for projects or other activities that may significantly impact local communities. 


\section{Human Rights Provisions under Chapter IV}

States have the duty to protect human rights. Enterprises should, within the framework of internationally recognised human rights, the international human rights obligations of the countries in which they operate as well as relevant domestic laws and regulations:

1. Respect human rights, which means they should avoid infringing on the human rights of others and should address adverse human rights impacts with which they are involved.

2. Within the context of their own activities, avoid causing or contributing to adverse human rights impacts and address such impacts when they occur.

3. Seek ways to prevent or mitigate adverse human rights impacts that are directly linked to their business operations, products or services by a business relationship, even if they do not contribute to those impacts.

4. Have a policy commitment to respect human rights.

5. Carry out human rights due diligence as appropriate to their size, the nature and context of operations and the severity of the risks of adverse human rights impacts.

6. Provide for or co-operate through legitimate processes in the remediation of adverse human rights impacts where they identify that they have caused or contributed to these impacts. 
Figure A1: All Human Rights Provisions Cited under 2011 Guidelines

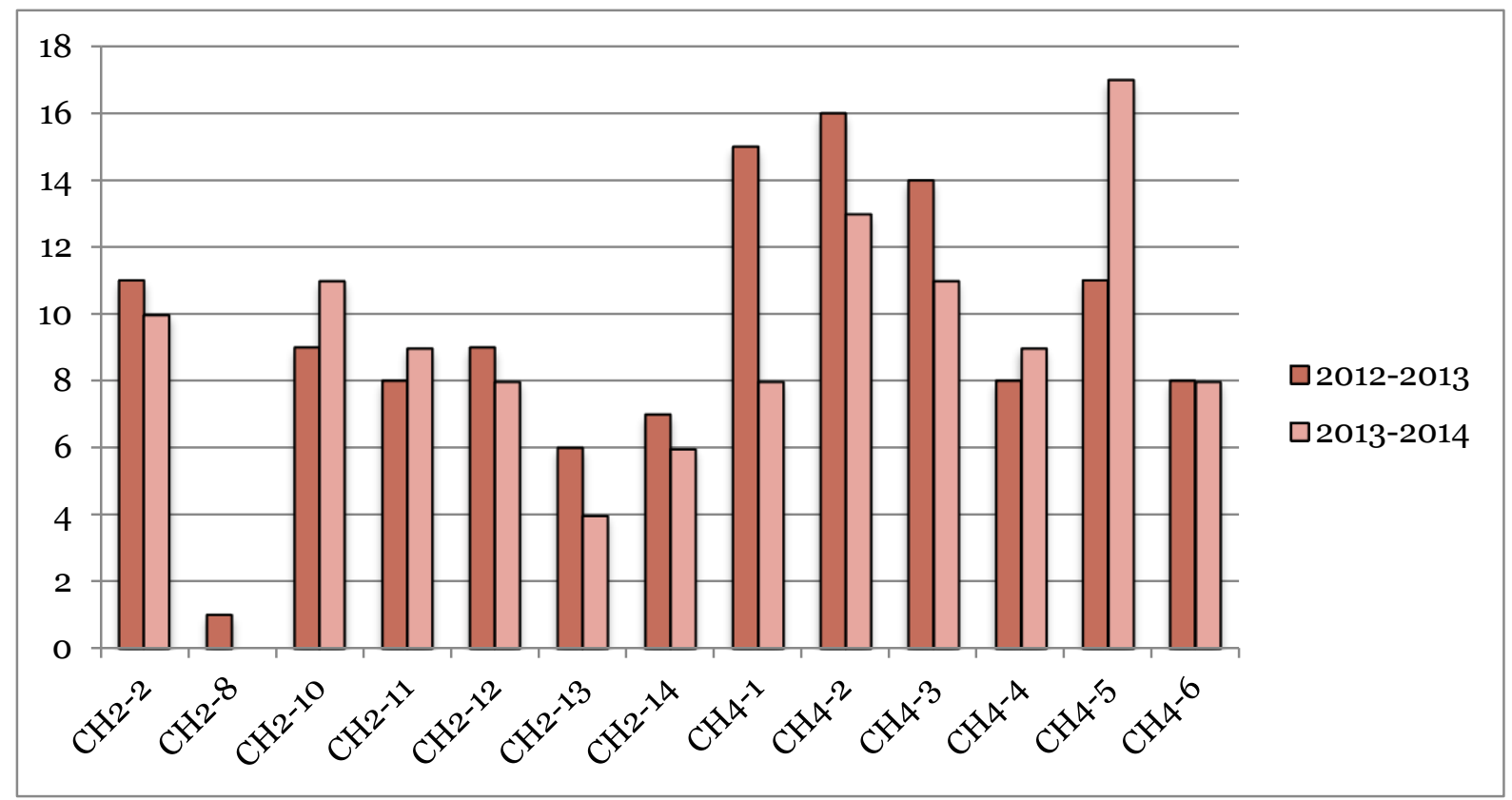




\section{APPENDIX II:}

\section{Cases in 2013-2014 cycle that cite Chapter IV, paragraphs 2 \& 5}

\begin{tabular}{|c|c|}
\hline $\begin{array}{l}\text { WeCAN vs Vero Insurance NZ } \\
\text { Ltd, IAG NZ Ltd, Tower } \\
\text { Insurance, Fletcher Construction } \\
\text { Company Ltd, Southern Response }\end{array}$ & $\begin{array}{l}\text { Complaints against construction and insurance } \\
\text { companies concerning housing and health abuses } \\
\text { related to the } 2010 \text { earthquake in New Zealand. }\end{array}$ \\
\hline $\begin{array}{l}\text { WeCAN vs. Southern Response \& } \\
\text { Earthquake Commission (EQC) }\end{array}$ & $\begin{array}{l}\text { Complaints against construction and insurance } \\
\text { companies concerning housing and health abuses } \\
\text { related to the same } 2010 \text { earthquake. }\end{array}$ \\
\hline Friends of the Earth vs. Rabobank & $\begin{array}{l}\text { Complaint against Dutch bank for financing palm oil } \\
\text { development without conducting adequate due } \\
\text { diligence. }\end{array}$ \\
\hline WeCAN vs. Arrow Intl & $\begin{array}{l}\text { Complaints against construction and insurance } \\
\text { companies concerning housing and health abuses } \\
\text { related to } 2010 \text { New Zealand earthquake. }\end{array}$ \\
\hline $\begin{array}{l}\text { Americans For Democracy and } \\
\text { Human Rights in Bahrain vs. } \\
\text { Formula One Management Ltd }\end{array}$ & $\begin{array}{l}\text { Complaint against UK companies for lack of due } \\
\text { diligence and mitigation of impact related to the } \\
\text { Formula One Grand Prix in Bahrain. }\end{array}$ \\
\hline $\begin{array}{l}\text { Center for Social Research and } \\
\text { Development et al vs Andritz AG }\end{array}$ & $\begin{array}{l}\text { Complaint against an Austrian engineering firm for } \\
\text { supplying technology to Laos for the Xayaburi dam, } \\
\text { alleging environmental and human rights impact in } \\
\text { Laos, Thailand, Cambodia, and Vietnam. }\end{array}$ \\
\hline $\begin{array}{l}\text { Canada Tibet Committee vs. China } \\
\text { Gold Int. Resources }\end{array}$ & $\begin{array}{l}\text { Complaint regarding the death of workers in manmade } \\
\text { landslide due to lack of due diligence and engagement, } \\
\text { by ignoring warnings and local protests. }\end{array}$ \\
\hline $\begin{array}{l}\text { International Union of Food, } \\
\text { Agriculture, Hotel, Restaurant, } \\
\text { Catering, Tobacco \& Allied } \\
\text { Workers' Association (IUF) vs } \\
\text { Mondelēz Int'l }\end{array}$ & $\begin{array}{l}\text { Complaint against a large food company for abusing } \\
\text { workers' rights in Pakistan. }\end{array}$ \\
\hline $\begin{array}{l}\text { Alleged human rights violations in } \\
\text { Israel (OECD data base does not } \\
\text { identify complainant) }\end{array}$ & $\begin{array}{l}\text { Complaint against a Danish subsidiary of UK } \\
\text { company for not conducting due diligence when } \\
\text { providing products/services to Israeli prison system. }\end{array}$ \\
\hline $\begin{array}{l}\text { Lawyers for Palestinian Human } \\
\text { Rights vs. G4S }\end{array}$ & $\begin{array}{l}\text { Complaint for providing, installing, and maintaining } \\
\text { equipment at facilities and operations that are in } \\
\text { breach of or associated with breaches of international } \\
\text { human rights law and principles. }\end{array}$ \\
\hline
\end{tabular}




\begin{tabular}{|c|c|}
\hline $\begin{array}{l}\text { UNI Global Union vs PROSEGUR } \\
\text { AB }\end{array}$ & $\begin{array}{l}\text { Complaint concerning interference with the right to } \\
\text { organize, evasion of collective bargaining obligations, } \\
\text { and harassment of trade union organizers and activists. }\end{array}$ \\
\hline $\begin{array}{l}\text { Int'l Union of Food Workers (IUF) } \\
\text { vs PepsiCo }\end{array}$ & $\begin{array}{l}\text { Complaint concerning trade union rights and } \\
\text { precarious work conditions. }\end{array}$ \\
\hline $\begin{array}{l}\text { Privacy International vs Vodafone } \\
\text { Cable, Interroute, Level 3, BT, } \\
\text { Verizon Enterprise, Viatel }\end{array}$ & $\begin{array}{l}\text { Complaint alleging that the telecom companies } \\
\text { facilitated mass interception of internet and telephone } \\
\text { traffic by granting the UKs Government } \\
\text { Communications Headquarters access to their fiber } \\
\text { optic networks for the Tempora surveillance program. }\end{array}$ \\
\hline WWF vs SOCO & $\begin{array}{l}\text { Complaint concerning oil exploration in Virunga } \\
\text { National Park (DRC) and lack of due diligence, } \\
\text { inadequate consultation with communities, and } \\
\text { informing the public of environmental, health and } \\
\text { safety risks; evading new laws and regulations. }\end{array}$ \\
\hline $\begin{array}{l}\text { Alleged violation of employee } \\
\text { rights in Bangladesh (OECD data } \\
\text { base does not identify complainant) }\end{array}$ & $\begin{array}{l}\text { Complaint against three German multinationals } \\
\text { concerning the } 2012 \text { fire in the Tazreen factory. }\end{array}$ \\
\hline $\begin{array}{l}\text { FIDH et al vs. Corriente Resources } \\
\text { Inc }\end{array}$ & $\begin{array}{l}\text { Complaint regarding inadequate stakeholder } \\
\text { engagement with indigenous communities, } \\
\text { environmental risks, poor working conditions, forced } \\
\text { displacement and involvement in state repression of } \\
\text { protests in Ecuador. }\end{array}$ \\
\hline Reprieve vs. BT & $\begin{array}{l}\text { Complaint regarding the telecommunications } \\
\text { company's involvement in providing infrastructure } \\
\text { related to the use of drones in Yemen. }\end{array}$ \\
\hline
\end{tabular}




\section{ENDNOTES}

${ }^{1}$ UNCTAD, 2002 World Investment Report (Geneva: UNCTAD, 2002).

${ }^{2}$ OECD, Declaration on International Investment and Multinational Enterprises (1976), Article II.

${ }^{3}$ Jill Murray, "A New Phase in the Regulation of Multinational Enterprises: The Role of the OECD," Industrial Law Journal, 30 (September 2001).

${ }^{4}$ See http://www.oecd.org/daf/inv/mne/50024913.pdf. , page 28.

5 The current description of NCPs role reads: "Adhering governments are obliged to set up National Contact Points (NCPs) whose main role is to further the effectiveness of the Guidelines by undertaking promotional activities, handling enquiries, and contributing to the resolution of issues that arise from the alleged non-observance of the guidelines in specific instances." See http://mneguidelines.oecd.org/ncps/.

${ }^{6}$ Murray, supra note 3, p. 260.

${ }^{7}$ On the MIA, see Andrew Walter, "NGOs, Business, And International Investment: The Multilateral Agreement on Investment, Seattle, and Beyond, Global Governance, 7 (JanuaryMarch 2001), and Stephen J. Kobrin, "The MAI and the Clash of Globalizations," Foreign Policy, 112 (Fall 1998).

${ }^{8}$ According to our count, based on slightly differing OECD and NGO documentation. More on methodology in later in the text.

9 "OECD Watch - 10 Years On: Assessing the contribution of the OECD Guidelines for Multinational Enterprises to responsible business conduct," available at http://oecdwatch.org/publications-en/Publication_3550.

${ }^{10}$ Norms on the Responsibilities of Transnational Corporations and Other Business Enterprises with Regard to Human Rights, U.N. Doc. E/CN.4/Sub.2/2003/12/Rev.2 (2003).

${ }^{11}$ John Gerard Ruggie, Just Business: Multinational Corporations and Human Rights (New York: W.W. Norton, 2013).

${ }^{12}$ UN Human Rights Council, Protect, respect and remedy: a framework for business and human rights : report of the Special Representative of the Secretary-General on the Issue of Human Rights and Transnational Corporations and Other Business Enterprises, John Ruggie, 7 April 2008, A/HRC/8/5, available at http://www.reports-and-

materials.org/sites/default/files/reports-and-materials/Ruggie-report-7-Apr-2008.pdf.

${ }^{13}$ See http://daccess-ddsny.un.org/doc/UNDOC/GEN/N03/567/36/IMG/N0356736.pdf?OpenElement.

${ }^{14}$ Statement by the UK NCP for the OECD Guidelines for Multinational Enterprises: Das Air, paragraph 13, available at http://oecdwatch.org/cases/Case_41.

${ }^{15}$ Ibid, paragraph 41.

${ }^{16}$ Ibid, paragraph 44.

${ }^{17}$ Final Statement by the UK NCP for the OECD Guidelines for Multinational Enterprises: Afrimex UK Ltd, paragraph 6, available at http://oecdwatch.org/cases/Case_114.

${ }^{18}$ Ibid, paragraph 16.

${ }^{19}$ Report of the Special Representative of the Secretary-General on the issue of human rights and transnational corporations and other business enterprises, John Ruggie, "Guiding Principles on Business and Human Rights: Implementing the United Nations 'Protect, Respect and Remedy Framework, UN Document A/HRC/17/31, 21 March 2011, available at http://www.ohchr.org/Documents/Publications/GuidingPrinciplesBusinessHR_EN.pdf. 
20 The Guidelines automatically cover all 34 OECD member states (Australia, Austria, Belgium, Canada, Chile, Czech Republic, Denmark, Estonia, Finland, France, Germany, Greece, Hungary, Iceland, Ireland, Israel, Italy, Japan, Korea, Luxembourg, Mexico, the Netherlands, New Zealand, Norway, Poland, Portugal, Slovak Republic, Slovenia, Spain, Sweden, Switzerland, Turkey, the United Kingdom, and the United States). In addition, twelve non-OECD members have chosen to adhere to them (Argentina, Brazil, Colombia, Costa Rica, Egypt, Jordan, Latvia, Lithuania, Morocco, Peru, Romania, and Tunisia).

${ }^{21}$ OECD Database of Specific Instances, available at https://mneguidelines.oecd.org/specificinstances.htm. Our best guess after checking with experts is that somewhere between ten to twenty-five percent of cases for the early years are missing because of poor reporting by NCPs.

${ }^{22}$ Terms of Reference for an Update of the OECD Guidelines for Multinational Enterprises, May 2010, page 2, available at http://www.oecd.org/corporate/mne/45124171.pdf.

232000 version of the OECD Guidelines for Multinational Enterprises, Chapter II, General Policies, Commentary 4, italics added.

${ }^{24}$ Announcement of the 2010 update of the OECD Guidelines for Multinational Enterprises, OECD Watch, May 2010, available at http://oecdwatch.org/news-en/official-announcement2010-update-of-the-oecd-guidelines-for-multinational-enterprises.

${ }^{25}$ Terms of Reference for an Update of the OECD Guidelines for Multinational Enterprises, May 2010, pages 3-4, available at http://www.oecd.org/corporate/mne/45124171.pdf.

${ }^{26}$ UK NCP, Americas for Democracy and Human Rights in Bahrain and Formula One World Championship Limited, Issues for further Examination, October 2014, available at http://oecdwatch.org/cases/Case_333.

${ }^{27}$ Human Rights and Formula One, ESPN, April 16, 2015, available at http://www.espn.co.uk/f1/story/_id/12695642/human-rights-formula-one.

${ }^{28}$ Chapter II, General Policies, Paragraph 10.

${ }^{29} \mathrm{See}$ http://www.oecd.org/corporate/mne/scopeoftheguidelinesandtheinvestmentnexus.htm.

${ }^{30}$ See "OECD Watch - 10 Years On," supra note 9.

${ }^{31}$ General Principles, paragraph 14.

${ }^{32}$ Ibid. The language is the same as UNGPs, Principle 13.

${ }^{33}$ Specific Instance Complaint submitted to OECD, October 2012, page 7, available at http://oecdwatch.org/cases/Case_262.

${ }^{34}$ According to the complaint, many of these communities also had additional legal protections under India's Scheduled Tribes or Other Traditional Forest Dwellers (Recognition of Forest Rights) Act, including having to give their consent before such a project moves forward.

${ }^{35} \mathrm{ABP}$ is a national pension fund for employees in government, public and education sectors in the Netherlands.

36 The complex governance structure of Norway's Government Pension Fund Global is outlined at https://www.regjeringen.no/en/topics/the-economy/the-government-pension-fund/governancemodel-for-the-government-pens/id699573/.

${ }^{37}$ OECD Watch summary of POSCO case, paragraph 3, available at http://oecdwatch.org/cases/Case_262.

${ }^{38}$ Norway NCP Final Statement on the POSCO case, page 19; available at https://www.regjeringen.no/contentassets/8d118fcbacdb41918795434c4838f848/nbim_final.pdf. ${ }^{39}$ Ibid, page 16. 
${ }^{40}$ OHCHR, The issue of Applicability of the Guidelines on Human Rights on Minority Shareholders, April 2013, available at http://www.ohchr.org/Documents/Issues/Business/LetterSOMO.pdf.

${ }^{41}$ Final Statement by Norway NCP on POSCO case, supra note 38, page 22.

42 Ibid.

${ }^{43}$ Ibid, page 42.

${ }^{44}$ Ibid, page 34 .

${ }^{45}$ Ibid.

${ }^{46}$ POSCO Case Press Release, October 2012, paragraph 2, available at http://oecdwatch.org/cases/Case_260.

${ }^{47}$ See, respectively, "Scope and Application of "Business Relationships" in the Financial Sector Under the OECD Guidelines for Multinational Enterprises," DAF/INV/RBS(2013)2/Rev1, 21 November 2013; "Application of the OECD Guidelines for Multinational Enterprises with Respect to Sovereign Wealth Funds and Central Banks," DAF/INV/RBC(2013)3/REV1, 21 November 2013; "Due Diligence in the Financial Sector: Adverse Impacts Directly Linked to Financial Sector Operations, Products or Services by a Business Relationship,"

DAF/INV/RBC(2014)1/Rev2; and "Scope and Application of "Business Relationships" in the Financial Sector Under the OECD Guidelines for Multinational Enterprises," DAF/INV/RBC/(2013)2/FINAL, 27 June 2014.

${ }^{48}$ Available at http://www.oecd.org/corporate/mne/GuidanceEdition2.pdf.

49 Procedural Guidelines, II.2 (b), available at http://www.oecd.org/corporate/mne/48004323.pdf.

${ }^{50}$ Available at http://www.international.gc.ca/trade-agreements-accords-commerciaux/topicsdomaines/other-autre/csr-strat-rse.aspx?lang=eng.

51 "Final Statement on the Request for Review regarding the Operation of China Gold International Resources Corp. Ltd., at the Copper Polymetallic Mine at the Gyama Valley, Tibet Autonomous Region," available at http://www.international.gc.ca/trade-agreements-accordscommerciaux/ncp-pcn/statement-gyama-valley.aspx?lang=eng. The company is listed on the Toronto Stock Exchange.

${ }^{52}$ Based on interviews with participants.

${ }^{53}$ In fact, the ECA was established by that country's government solely for a public purpose and is an "official" agency by its own description, even if it is self-financing. (The authors checked its website.) Thus like any other ECA it also falls under Pillar 1 of the UN Guiding Principles concerning state obligations and policy rationales to ensure that business enterprises within its purview respect human rights. 